\title{
Note
}

\section{Diagnostic significance of serum 1 $\alpha, 25$-dihydroxyvitamin D level in a dog with hypercalcemia induced by a parathyroid adenoma}

\author{
Akihiro Murakami ${ }^{1,2}$, Kazushi Asano ${ }^{2}$
}

\begin{abstract}
A 10-year-old castrated Miniature Dachshund with hypercalcemia showed normal serum levels of parathyroid hormone (PTH-intact) and parathyroid hormone-related protein (PTHrP). Computed tomography revealed no mass formations in the cervical area. However, serum concentration of $1 \alpha, 25$-dihydroxyvitamin $\mathrm{D}\left(1,25(\mathrm{OH})_{2} \mathrm{D}\right)$ was increased and a small nodule in the right thyroid gland was detected by using ultrasound. Therefore, the right total thyroidectomy was carried out. The resected mass was histopathologically diagnosed as a parathyroid adenoma. The patient showed no complications and clinical signs after surgery, and the serum calcium level decreased to the normal range. This case report suggests that the measurement of serum $1,25(\mathrm{OH})_{2} \mathrm{D}$ can be useful for finding out canine parathyroid adenoma patients with hypercalcemia, even when their serum PTH-intact and PTHrP levels are within the normal range.
\end{abstract}

Key words : canine, parathyroid adenoma, 1 $\alpha, 25$-dihydroxyvitamin D

1) Hayama Animal Hospital, 639 Horiuchi, Hayama-machi, Miura-gun, Kanagawa 240-0112, Japan

2) Laboratory of Veterinary Surgery, Department of Veterinary Medicine, College of Bioresource Siences, Nihon University, 1866 Kameino, Fujisawa, Kanagawa 252-0880, Japan

Corresponding author : Akihiro Murakami, Hayama Animal Hospital, 639 Horiuchi, Hayama-machi,

Miura-gun, Kanagawa 240-0112, Japan, TEL: 046-875-1199 FAX: 046-876-1524

E-mail address : murakamiakihiro322@gmail.com

Received : August 14, 2015 / Accepted : June 14, 2017 


\section{上皮小体腺腫による高カルシウム血症の犬において 血清活性型ビタミンD ( 1 $\alpha, 25$-dihydroxyvitamin D) 濃度測定が診断に効果的であった 1 例}

村上昭弘 ${ }^{1,2}$ 、浅野和之 ${ }^{2}$

犬の上皮小体腺腫は発生がまれな腫瘍であり、上皮小体ホルモン（parathyroid hormone, PTH）の過㮃分泌を伴う原発性 上皮小体機能立進症が発生することがある [1,2]。原発性上皮小体機能立進症は高カルシウム血症を引き起こし、それに伴っ て食欲不振や多飲多尿などの臨床症状が発現する。一般的には高カルシウム血症の犬において、低リン血症およびPTHintact值の上昇が認められる場合には原発性上皮小体機能立進症と診断されて、上皮小体の腫瘍化または過形成が強く疑わ れる [1-5]。しかし、原発性上皮小体機能立進症の犬210例の回顧研究において、低リン血症を示した症例は 65\%（136/210例）、 PTH-intact值が上昇していた症例は $27 \%$ （50/185例）であったことが報告されており、原発性上皮小体機能充進症であって も高カルシウム血症以外の所見がそしいために、その診断に苦慮することがある [4]。

ヒトでは、高カルシウム血症が認められるものの、血清 PTH-intact值の上昇が認められない原発性上皮小体機能立進症の 症例に対し、補助的な検査として血清活性型ビタミン D $\left(1 \alpha, 25\right.$-dihydroxyvitamin $\left.\mathrm{D},\left[1,25(\mathrm{OH})_{2} \mathrm{D}\right]\right)$ 值、尿中カルシウム排泄量、 シンチグラフィなどの検査が行われ、診断を下すことが可能となっている[6-12]。

今回我々は、PTH-intact值が高值を示さなかったミニチュア・ダックスフンドの上皮小体腺腫の症例に対し、血清 $1,25(\mathrm{OH})_{2} \mathrm{D}$ 值の測定を実施したところ異常高值がみられ、上皮小体腺腫の診断に効果的であったため、その概要を報告する。

症例はミニチュア・ダックスフンド、去勢雄、10歳齢、体重は7.75kgであり、食欲低下、活動性低下を主訴に来院した。

初診時の身体検査では明らかな異常は認められず、問診にて食事内容からビタミン Dの過剩摂取は否定されたものの、血 液化学検査において血清中のカルシウム值が $14.9 \mathrm{mg} / \mathrm{dl}$ (アルブミン補正值 $14.5 \mathrm{mg} / \mathrm{dl}$ )、リン值が $2.6 \mathrm{mg} / \mathrm{dl}$ 示したことか ら、第3病日に精査を行うこととなった。血液および血液化学検査において、血清カルシウム值（16.0mg/dl）および血清ア ルカリフォスファターゼ值 $(869 \mathrm{U} / 1)$ の上昇が認められた以外には、著変は認められなかった（表1）。尿検査では、細菌感

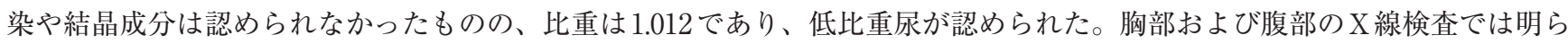
かな異常はみられなかったが、腹部超音波検査では、左右の副腎に、変形を伴わない両側性の腫大が認められた。（左側副腎： 最長径 $18 \mathrm{~mm}$ 最大厚 $12 \mathrm{~mm}$ 、右側副腎：最長径 $23 \mathrm{~mm}$ 最大厚 $11 \mathrm{~mm}$ )

内分泌学的検査として甲状腺ホルモン（T4、FT4、TSH）の測定を実施したところ、いずれも参照基準值内であった。 $\mathrm{ACTH}$ 刺激試験を実施したところ、刺激後 1 時間後のコルチゾール值は $25.3 \mu \mathrm{g} / \mathrm{dl}$ と軽度高值を示した。さらに、イオン化 カルシウム、PTH関連蛋白測定および化学発光酵素免疫測定法（CLEIA 法）によるPTH-intactの測定（モノリス、東京） を実施したところ、イオン化カルシウムは $1.85 \mathrm{mmol} / \mathrm{L}$ 高值を示し、PTH関連蛋白は $1.0 \mathrm{pmol} / \mathrm{L}$ 以下、PTH-intactは $7.9 \mathrm{pg} /$ $\mathrm{ml}$ と参照基準值内であった（表2）。

1）葉山どうぶつ病院 †240-0112 神奈川県三浦郡葉山町堀内 639

2) 日本大学生物資源科学部獣医学科獣医外科学研究室 $\bar{T} 252-0880$ 神奈川県藤沢市亀井野 1866

連絡責任者：村上昭弘 葉山どうぶつ病院 テ240-0112 神奈川県三浦郡葉山町堀内 639

電話番号：046-875-1199 FAX番号：046-876-1524

メールアドレス : murakamiakihiro322@gmail.com

受付日：2015年8月 14 日、採択日：2017年6月14日 
表 1. 第 3 病日の血液および血液化学検査所見

\begin{tabular}{|c|c|c|c|c|c|}
\hline WBC $(/ \mu \mid)$ & 12,200 & $\operatorname{ALT}(\mathrm{U} / \mathrm{I})$ & 33 & BUN (mg/dl) & 12.9 \\
\hline $\mathrm{RBC}(/ \mu \mathrm{l})$ & 8,000,000 & ALP (U/I) & 869 & $\mathrm{Cr}(\mathrm{mg} / \mathrm{dl})$ & 0.5 \\
\hline $\mathrm{Hb}(\mathrm{g} / \mathrm{dl})$ & 18.9 & TBil (mg/dl) & 0.7 & $\mathrm{Ca}(\mathrm{mg} / \mathrm{dl})$ & 16.0 \\
\hline PCV (\%) & 56.3 & TCho (mg/dl) & 242 & $P(m g / d l)$ & 4.0 \\
\hline MCV (fl) & 70.4 & $\mathrm{TP}(\mathrm{g} / \mathrm{dl})$ & 6.9 & $\mathrm{Na}(\mathrm{mEq} / \mathrm{l})$ & 146 \\
\hline $\mathrm{MCH}(\mathrm{pg})$ & 23.6 & Alb (g/dl) & 3.9 & $\mathrm{~K}(\mathrm{mEq} / \mathrm{l})$ & 4.0 \\
\hline $\mathrm{MCHC}(\mathrm{g} / \mathrm{dl})$ & 33.6 & Glu (mg/dl) & 101 & $\mathrm{Cl}(\mathrm{mEq} / \mathrm{l})$ & 110 \\
\hline Plt $(/ \mu \mathrm{l})$ & 535,000 & Lip (IU/I) & 128 & & \\
\hline
\end{tabular}

表 2. 第 3 病日の内分泌検査所見

\begin{tabular}{|c|c|c|}
\hline & 結果 & 基準値 \\
\hline $\mathrm{T} 4(\mu \mathrm{g} / \mathrm{dl})$ & 1.7 & $1.1-3.6$ \\
\hline FT4 (ng/dl) & 1.7 & $0.5-3.0$ \\
\hline TSH (ng/ml) & 0.11 & 0.08-0.32 \\
\hline \multicolumn{3}{|l|}{ ACTH 刺激試験 } \\
\hline 刺激前コルチゾール $(\mu \mathrm{g} / \mathrm{dl})$ & 4.6 & $1.0-7.8$ \\
\hline 刺激後コルチゾール $(\mu \mathrm{g} / \mathrm{dl})$ & 25.3 & 20 以下 \\
\hline イオン化 Ca (mmol/L) & 1.85 & $1.24-1.56$ \\
\hline PTH-intact $(\mathrm{pg} / \mathrm{ml})$ & 7.9 & 8.0-35.0 \\
\hline PTH 関連蛋白（pmol/L） & 1.0 以下 & $0.0-1.5$ \\
\hline
\end{tabular}

以上の検査結果からは確定診断に至らなかったため、第3病日から高カルシウム血症に対する対症治療を行った。血清力 ルシウム值をモニタリングしながら生理食塩水輸液（100-150ml/kg/day IV or SC:テルモ生食、テルモ)、フロセミド (2-4mg/ $\mathrm{kg} /$ day SC or PO : ラシックス、サノフィ)、ゾレドロン酸 $(0.25 \mathrm{mg} / \mathrm{kg}$ IV : ゾメタ点滴静注、ノバルティスファーマ)、サ ケカルシトニン（3-6IU/kg IM：サーモストン筋注、富士製薬工業）などの治療を行った。また、クッシング症候群の可能 性を考慮してトリロスタン（30mg/head SID PO：アドレスタン、共立製薬）の投与も行った。しかし、それらの治療に対 する反応は乏しく、高カルシウム血症は持続して臨床症状の改善は認められなかった。

第7病日に骨病変や腫瘍性疾患の精査のため、全身麻酔下にて CT検査を実施した。CT撮影はまず全身をスクリーニング 撮影し、造影剤投与後 120 秒後に再び全身撮影を行った。造影剂はイオパミドール（イオパミドール 300 注シリンジ $100 \mathrm{ml} 「 \mathrm{HK} 」:$ $300 \mathrm{mgI} / \mathrm{ml}$ 、光製薬）を使用し、投与量は $2 \mathrm{ml} / \mathrm{kg}$ 、造影剤注入速度は $2.0 \mathrm{ml} /$ 秒に設定し、オートインジェクターにて注入し た。しかしCT検査では、明らかな骨病変や腫瘤性病変を疑う所見は認められなかった（図 1 )。

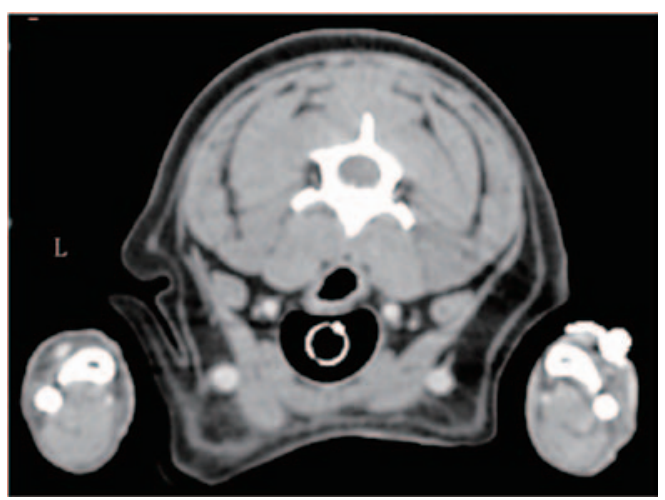

図 1. 頝部の造影 CT 画像所見

第 15 病日、上記の検査所見や除外診断より、鑑別診断として上皮小体疾患が疑われたため、再度PTH-intact值の測定を行っ た。血清カルシウム值が $14.9 \mathrm{mg} / \mathrm{dl}$ の時に血清を採取し、CLEIA法（モノリス、東京）による再測定、並びに電気化学発光 免疫測定法（ECLIA 法、保健科学研究所、神奈川）にて測定を行った。CLEIA 法では $15.4 \mathrm{pg} / \mathrm{ml}$ （参照基準值：8.0-35.0pg/ $\mathrm{ml}$ )、ECLIA 法では $8.0 \mathrm{pg} / \mathrm{ml}$ （参照基準值 : $10-65 \mathrm{pg} / \mathrm{ml}$ ）であり、第3病日と同様の所見であった。さらに追加検査として、 
血清 $1,25(\mathrm{OH})_{2} \mathrm{D}$ 值（RIA 法、保健科学研究所、神奈川）を測定したところ、317.4pg/ml（参照基準值：20-50pg $/ \mathrm{ml}$ ）と高值 を示した。また、画像診断として䅡部の超音波検查を行ったところ、左側の上皮小体は $1.4 \mathrm{~mm} \times 1.5 \mathrm{~mm}$ であったが、右側 では甲状腺の皮膜に隣接した実質に $7.0 \mathrm{~mm} \times 2.5 \mathrm{~mm}$ の低エコー性腫瘤が描出され、腫大した上皮小体が疑われた（図 $2 \mathrm{a}$, 図 $2 b)$ 。

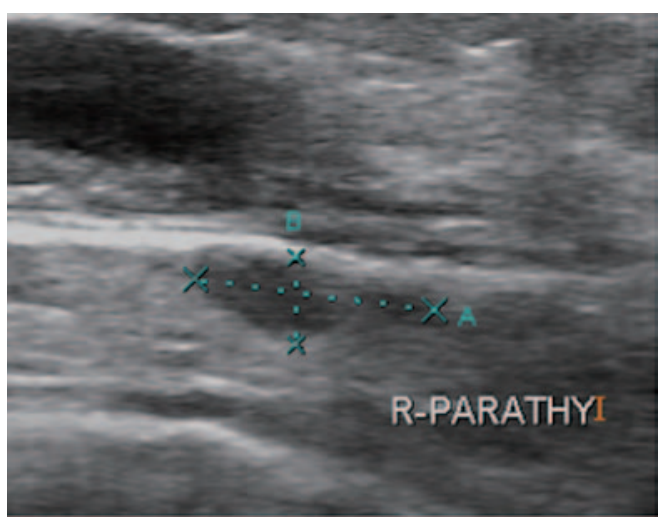

図2. 右側甲状腺の超音波検査所見 a. 矢状断面 右側甲状腺実質に、周囲組織に比べ低エコ一性の腫瘤病変 $(7.0 \mathrm{~mm} \times 2.5 \mathrm{~mm})$ が描出され、腫大した上皮 小体と考えられた。

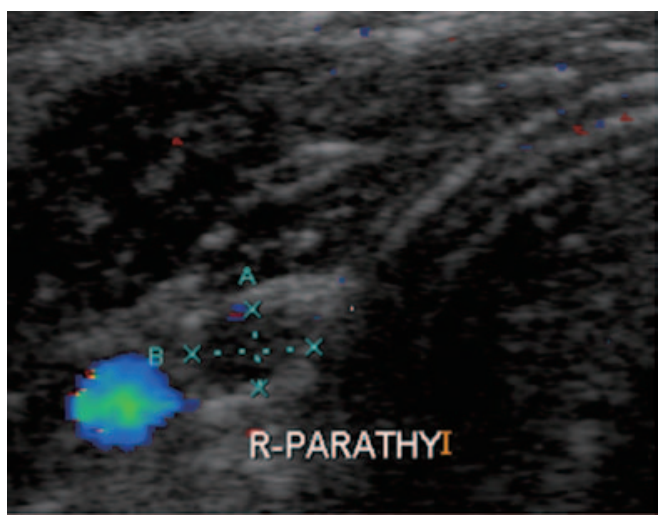

b. 横断面

以上の検査所見から右側上皮小体腫大とそれによる原発性上皮小体機能充進症が最も疑われたため、第 24 病日に右側上皮 小体の切除を行った。全身麻酔下にて頝部腹側正中を切開し、胸骨舌骨筋を左右に分離して気管を露出し、両側の甲状腺を 肉眼的に確認したところ、左側の正常な上皮小体と比較して右側に腫大した上皮小体が確認された。そこで、右側甲状腺お よび上皮小体の片側全切除を行った（図3）。

病理組織学的検査では、摘出した腫瘤は上皮小体腺腫であり、内上皮小体が腫瘍化していた。その他、外上皮小体や甲状 腺には特に異常は認められなかった（図4）。

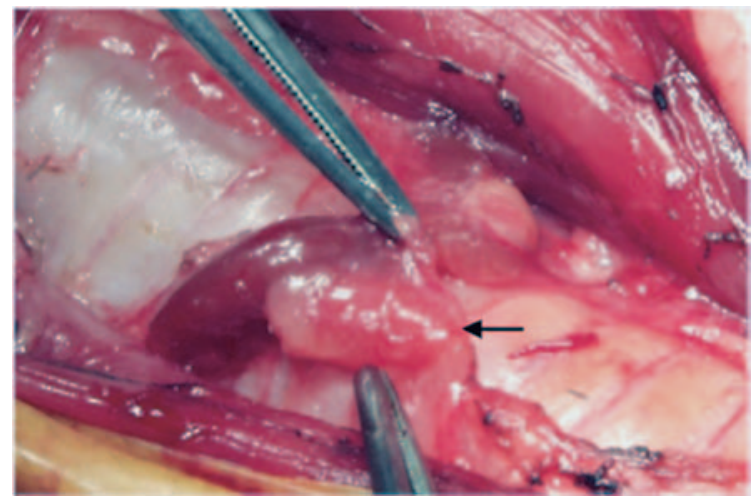

図3. 術中所見 右側甲状腺表面に腫大した上皮小体（矢印）が確認された。

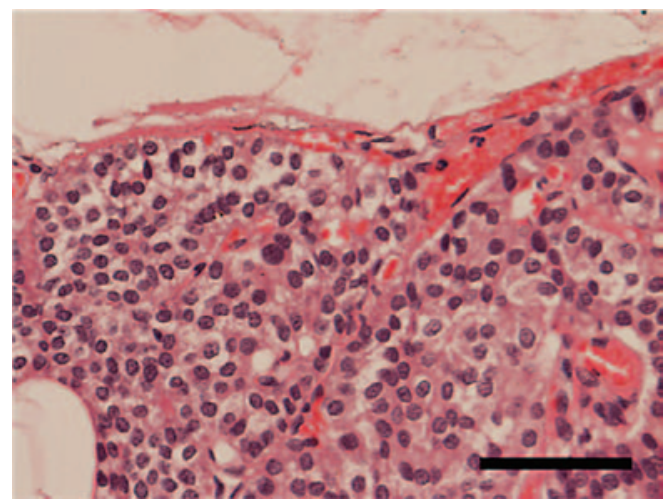

図 4. 病理組織検査所見 (HE 染色、Bar=50 $\mu \mathrm{m}$ ) 腫瘍組織を取り囲むように薄い被膜が形成されてい る。浸潤性増殖は確認されず、上皮小体腺腫と診断 された。

術後、臨床症状は徐々に改善し、術前高值を示していた血清カルシウム濃度は、術後 2 日目には正常範囲内にまで低下し、 その後も正常範囲内を推移した（図5)。また、第 30 病日目に測定した血清 $1,25(\mathrm{OH})_{2} \mathrm{D}$ 值は $100.9 \mathrm{pg} / \mathrm{ml}$ あ゙あ、明らかな低 下が認められた。現在、術後 1 年を経過した段階であるが、臨床症状はほとんど消失し、血清カルシウム濃度も正常值を示し、 良好に推移している。 


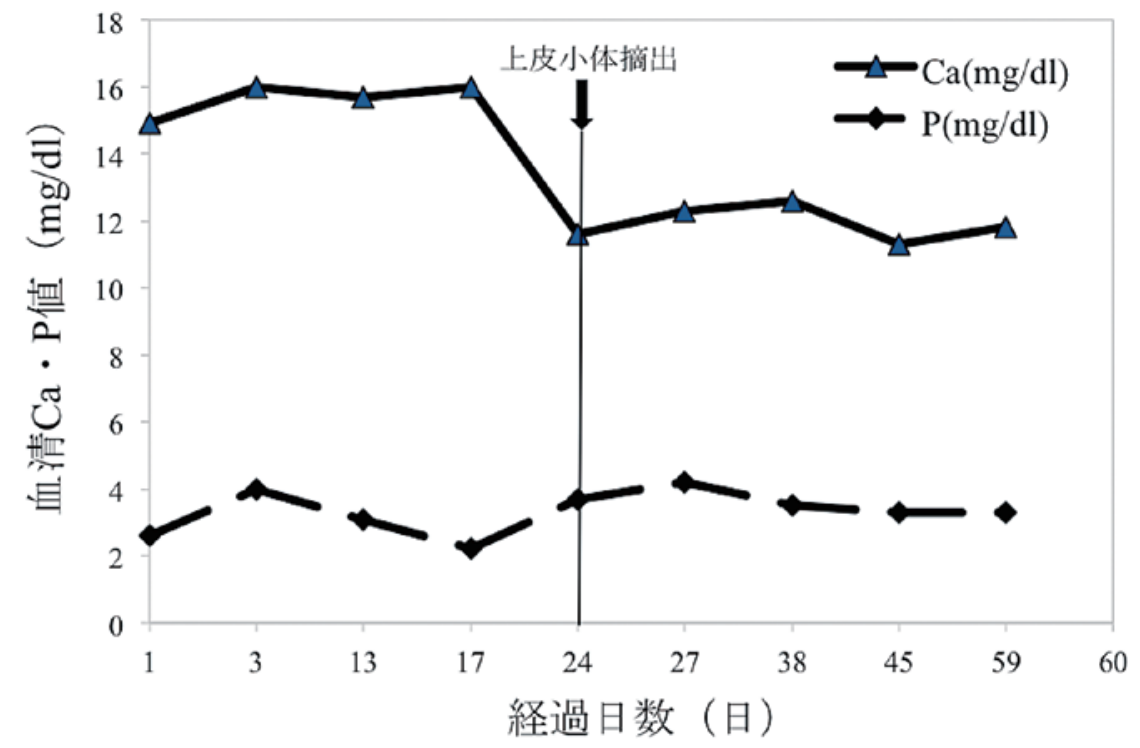

図 5. 周術期の血清カルシウム・リン値の推移

犬の原発性上皮小体機能㐫進症の診断は、高カルシウム血症、低リン血症、並びにPTH- intact 值の上昇を指標に進めら れている。しかし、本症例では高カルシウム血症が認められたものの、PTH-intact值はCLEIA 法拉よびECLIA 法を用いて 計 3 回測定したが、いずれも典型的な異常高值を示さなかった。これはPTHの分泌が、増加した血中カルシウムや過剩な 1,25(OH) $)_{2} \mathrm{D}$ からのネガティブフィードバックによって制御されたものと考えられ[1-4]、本症例では PTH-intact值が低く測定 されたと考えられた。このように高カルシウム血症の原因の追求に、PTH-intact值は、イオン化カルシウム濃度と組み合わ せた繰り返しの測定による、慎重な評価が必要と考えられた。

一方、医学領域においては $1,25(\mathrm{OH})_{2} \mathrm{D}$ 值が一つの診断基準になっている $[10-12]$ 。ビタミン D は肝臟で 25 位に水酸化をうけ 25-hydroxyvitamin $\mathrm{D}(25(\mathrm{OH}) \mathrm{D})$ となり、次いで腎臟で $1 a$ 位あるいは 24 位に水酸化をうけて $1,25(\mathrm{OH})_{2} \mathrm{D}$ あるいは $24,25(\mathrm{OH})_{2} \mathrm{D}$ になる。この代謝過程のなかでPTHは $1 a$ 位の水酸化を促進するといわれている。よって原発性上皮小体機能光進症の症例 では、1,25(OH) $)_{2} \mathrm{D}$ 值が高値を示すと考えられている[10-12]。本症例においても、1,25(OH) $2 \mathrm{D}$ 值は異常高值がみられ、治療後 には低下がみられた。したがって、PTH-intact值が正常值を示す高カルシウム血症において、血清 $1,25(\mathrm{OH})_{2} \mathrm{D}$ 值の測定が鑑 別診断に有効であることが示唆された。

これまで、原発性上皮小体機能立進症における $1,25(\mathrm{OH})_{2} \mathrm{D}$ 值を検討した獣医学文献は少ない。以前の報告では、1,25(OH $)_{2} \mathrm{D}$ 值は健常大群と原発性上皮小体機能立進症群の間に有意差がなかった[13]。しかし、その報告では原発性上皮小体機能充進 症と腎機能不全が併発した例が含まれており、比較検討数も少ないという点から、今後さらなる検討が必要であると考えら れた。

また、本症例は術前にCT検査を実施したが、局在診断にはいたらなかった。これは医学領域での報告[14] と同様に、腫瘤 が小さい場合にはCT検查での診断が難しいと考えられた。今回の結果から、このように腫瘤が小さい場合には頝部超音波 検查が有用である可能性が示唆された。

結論として、原発性上皮小体機能立進症を伴う上皮小体腺腫の犬において、PTH-intact值が正常であるにも関わらず、血 清 $1,25(\mathrm{OH})_{2} \mathrm{D}$ 值は高値を示した。さらに、頚部の詳細な超音波検查によって右側上皮小体の腫大が確認され、外科的切除によっ て良好な経過が得られた。大の機能性上皮小体腺腫の診断には血液化学検查、内分泌学的検查、画像診断を組み合わせなが ら総合的に判断し、診断に至らないようであれば、血清 $1,25(\mathrm{OH})_{2} \mathrm{D}$ 值の測定が、補助的診断材料として有用である可能性が 示唆された。 


\section{参考文献}

[1] Richard WN (2009):Disorders of the parathyroid Gland,Small Animal Internal Medicine.Richard WN,et al eds,4th ed,pp.715720,MOSBY,Missouri.

[2 ] Feldman EC (2009):Disorders of the parathyroid Glands, Textbook of veterinary internal medicine.Ettinger SJ,et al eds,7th ed,pp.17221743,SAUNDERS,Missouri.

[ 3 ] Bonczynski J (2007): Primary hyperparathyroidism in dogs and cats.Clin Tech Small Anim Pract,May;22(2):70-74.

[4] Feldman EC, Hoar B, Pollard R, Nelson RW (2005): Pretreatment clinical and laboratory finding in dogs with primary hyperparathyroidism:210case (1987-2004).J Am Vet Med Assoc,Sep1;227(5):756-761.

[ 5 ] Berger B, Feldman EC (1987):Primary hyperparathyroidism in dogs:21 cases (1976-1986).J Am Vet Med Assoc,Aug1;191(3):350-356.

[6 ] Maruani G, Hertig A, Paillard M, Houillier P (2003):Normocalcemic primary hyperparathyroidism: evidence for a generalized targettissue resistance to parathyroid hormone.J Clin Endocrinol Metab,Oct;88(10):4641-4648.

[7] Michels TC, Kelly KM (2013) : Parathyroid disorders.Am Fam Physician,Aug15;88(4):249-257.

[8] 櫻山 由利, 宮内 大成, 伊藤 晴夫, 島崎 淳 (1986):原発性上皮小体機能立進症の診断.日泌尿会誌,77(9): 1438-1444.

[9] 石川 泰章, 郡 健次郎, 井口 正典, 片岡 喜代徳, 加藤 良成, 高田 晶彦, 高村 知諭, 片山 孔一, 梅川 徹, 尼崎 直也, 山手 貴詔, 栗田 孝 (1993):原発性上皮小体機能充進症における術前診断法の検討-特に正カルシウム血症を呈した症例について-.日 泌尿会誌,84(3):546-551.

[10] Tebben PJ, Singh RJ, Clarke BL, Kumar R (2004):Fibroblast growth factor 23, parathyroid hormone, and 1 $\alpha, 25$-dihydroxyvitamin D in surgically treated primary hyperparathyroidism.Mayo Clin Proc, Dec;79(12):1508-1513.

[11] Vieth R, Bayley TA, Wafish PG, Rosen IB, Pollard A (1991):Relevance of vitamin D metabolite concentrations in supporting the diagnosis of primary hyperparathyroidism.Surgery,Dec;110(6):1043-1047.

[12］海上 寛 (1982):副甲状腺機能異常症における血中ビタミンDメタボライト值.日内分泌会誌,58:234-247.

[13] Gerber B, Hauser B, Reusch CE (2004):Serum levels of 25-hydroxycholecalciferol and 1,25-dihydroxycholecalciferol in dogs with hypercalcaemia.Vet Res Commun,Nov;28(8):669-680.

[14] Prommegger R, Wimmer G, Profanter C, Sauper T, Sieb M, Kovacs P, Bale R, Putzer D, Gabriel M, Margreiter R (2009):Virtual neck exploration: a new method for localizing abnormal parathyroid glands.Ann Surg, Nov;250(5):761-765. 